\title{
Habermas and KieRKEgaARd on EXIstential Ethics AND Liberal EugENICS ${ }^{1}$ \\ Mélissa Fox-Muraton \\ Universidad Clermont Auvergne, Francia
}

\section{Resumen}

En su obra Die Zukunft der menschlichen Natur (El futuro de la naturaleza bumana), Jürgen Habermas evoca los problemas ocasionados por la ingeniería genética de los seres humanos con respecto a las posibilidades de auto-definición y de nuestra comprensión de nosotros mismos como seres normativos. En respuesta a estos problemas, Habermas sugiere que la ética kierkegaardiana ofrece un argumento fuerte contra el derecho de modificar la substancia biológica de la naturaleza humana. En este artículo, sugerimos que los argumentos de Habermas se basan en una comprensión ontológicamente errónea de la naturaleza de la existencia humana y de la exigencia moral. Por consiguiente, recurrir como hace Habermas a una ética existencial es ineficaz. Demostraremos entonces cómo una ética existencial inspirada de Kierkegaard podría ofrecer un argumento más sólido que lo propuesto por Habermas.

Palabras clave: ética existencial, eugenesia liberal, naturaleza humana, exigencia moral, el yo.

\section{Abstract}

In Die Zukunft der menschlichen Natur (The Future of Human Nature), Jürgen Habermas evokes the problems posed by the genetic engineering of human beings with regard to the possibilities of self-definition and of understanding ourselves as normative beings. In response to these problems, Habermas suggests that Kierkegaard's ethics offer a solid argument against the right to modify the biological substance of human nature. In this paper, we will argue that Habermas's arguments are based on an ontologically flawed understanding of the nature of human existence and moral requirement. As such, his appeals to an existential ethics are ineffectual. We will then demonstrate how a Kierkegaardian existential ethics could offer a more solid argument than that drawn out by Habermas.

\footnotetext{
${ }^{1}$ Recibido: 15 de febrero de 2016. Aceptado: 5 de marzo de 2016.
} 
Key words: existential ethics, liberal eugenics, human nature, moral requirement, self.

In Die Zukunft der menschlichen Natur (The Future of Human Nature), Jürgen Habermas evokes the problems that modern developments in genetic engineering and the move toward a liberal eugenics pose for understandings of human nature and responsibility, and more importantly for moral understandings of human shared existence. In a world in which man can intervene on the organic make-up of other individuals, so that the biological foundations upon which individuality and subjectivity are later to be constructed and de-constructed depend no longer on contingency, but rather on an intentional project determined by someone other than the subject himself, will we still be able to understand ourselves as "normative beings; even more, as beings who expect responsibility and solidarity from each other, as well as equal respect?" Habermas asks², "If one person makes for another an irreversible decision [...] then the symmetry of responsibility that exists in principle between free and equal persons is necessarily limited"3. Will we in such cases still be able to conceive of ourselves as responsible for our own biographies, able to determine for ourselves who we are against the limitations of biological circumstances defined externally? And will an "ethics of the ability-to-be-ourselves (Ethik des Selbstseinkönnens)" still make sense? ${ }^{4}$.

What is striking in these seemingly un-Kierkegaardian reflections is that Habermas's primary interlocutor in the opening chapter of Zukunft is none other than Søren Kierkegaard, whom Habermas cites as the first thinker to shift the focus of ethics away from normative concerns to the existential question of measuring an achieved or failed life through the post-metaphysical concept of "ability-to-be-oneself," and thus as that philosopher who may be able to offer the strongest arguments against the right to artificially modify the biological nature of other human beings. Despite this privilege awarded to Kierkegaard, however, Habermas's appeal unfortunately has little resonance, and it is unclear whether he sees Kierkegaard's philosophy as one which can resolve the situation, or rather

${ }^{2}$ Jürgen Habermas, Die Zukunft der menschlichen Natur: Auf dem Weg zu einer liberalen Eugenik?, Frankfurt am Main: Suhrkamp 2002 (2005), p. 32. (Our translations from the German for all references to Habermas.)

${ }^{3}$ Ibid., pp. 31-32.

${ }^{4}$ Ibid., p. 32.

${ }^{5}$ Ibid., p. 17. 
as the very root of the problem. More importantly, however, Habermas's dialogue with Kierkegaard remains superficial, as Karin Christiansen ${ }^{6}$ points out, qualifying Habermas's appropriation of Kierkegaard as a "(no doubt unintentional) silencing" of the latter, and arguing that not only does Habermas fail to give an adequate account of the existential impact of eugenics on the genetically modified individual, but also that Habermas's perspective occults Kierkegaard's own positions?

In appealing to Kierkegaard in the opening chapter of Zukunft, Habermas marks a radical departure from his traditional accounts of socially constructed normative ethics. And indeed the turn seems justified, to the extent that the specific question posed by the practice of liberal eugenics may well render ineffectual any linguistically or socially derived normative account of responsibility toward others. If we presuppose that genetic intervention on human beings could transform these beings into something other than human beings, could modify the biological nature of the individual to an extent that one may no longer be recognized as part of a human community, we would in fact be confronted with a situation to which linguistic constructivist accounts of normative ethics can offer no response, an unprecedented situation for which there exist no norms to which we may appeal. Habermas's appeal to Kierkegaard functions thus as an implicit appeal to a non-normative ethico-existential requirement. At the same time, Habermas is quick to abandon the existential stance, and to return to a normative constructivist approach in his discussion of the problem of eugenics.

Though existential philosophy has traditionally been plagued with the problem of articulating an understanding of ethics as being-with or being-together in a shared moral sphere, this paper will argue that a reconsideration of Kierkegaard's existential approach to ethics could offer more solid grounding for the constitution of an existential ethics than that we can find in Sartrean or Heideggerian-inspired existential approaches. We will then demonstrate that there is a fundamental confusion in Habermas's articulation of the relationship between the existential appropriation of one's own life and the possibility to construct normative principles, which not only weakens his argument against eugenics, but also falsifies his dialogue

\footnotetext{
${ }^{6}$ To the best of our knowledge, this is the only article directly dealing with Habermas's reading of Kierkegaard in Zukunft.

${ }^{7}$ Karen Christiansen, "The silencing of Kierkegaard in Habermas' critique of genetic enhancement”, Medicine, Health Care and Philosophy, no. 12.2, 2009, p. 155.
} 
with Kierkegaard. Finally, we will examine how Kierkegaard's existential philosophy could better serve Habermas's arguments.

\section{The Problem of Existential Ethics: Ontological solitude and moral requirement}

Existential philosophy has traditionally been plagued with the incapacity of articulating an account of shared existence and responsibility toward others. If we seek to abandon an intellectualist or essentialist position, and take concrete human existence as the starting-point of philosophy, it would seem that we necessarily fall into the trap of some form of relativism or solipsism. This is particularly apparent in Jean-Paul Sartre's account of the existence of other subjects "for me"; while Sartre strives to claim that "existentialism is a humanism", he fails to give an adequate account as to how the move toward a being-with could be made. As Sartre writes, "the man who reaches himself directly through the cogito also discovers all other [human beings], and discovers them as the condition of his existence. He realizes that he can be nothing (in the sense that one says that one is spiritual, or that one is mean, or that one is jealous) if others do not recognize him as such". Sartre's analysis evokes a major difficulty for thinking the ethical from an existential perspective, for if recognition is certainly an important element of life in the shared social sphere, such recognition, as determination (one is what one is because others see one as such), not only excludes true thinking of intersubjectivity, but also undermines the reality both of ethical judgment and of individual personality. If there is no reality to the individual's ethical character independent of the judgments and evaluations imposed upon one by others, it would seem that this attempt to reintroduce the ethical sphere into his existential thinking of the individual undermines Sartre's own project-for if one is determined by how one is perceived, then it is questionable whether it is possible at all to construct one's identity-i.e., to maintain the idea that the individual constructs himself through the choices that he makes-and to maintain the affirmation that "existence precedes essence". As Rachel Bespaloff wrote in an early critique of Sartre's perspective, the Sartrean account of existential ethics leads down not only to a "hollow subjectivity," but also reveals itself to be incapable of establishing

${ }^{8}$ Jean-Paul Sartre, L'existentialisme est un humanisme, Paris: Gallimard 1946 (1996), pp. 58-59 (our translation).

${ }^{9}$ Ibid., p. 26. 
a "veritable communion between beings," and as such, "existentialism can only succeed in establishing an aggressive solidarity in a hostile or tamed world" 10 .

The problem Sartre encounters in attempting to offer "a positive theory of the existence of the other [that] should be able at once to avoid solipsism and to get by without recourse to God" 11 is not specific to Sartre's philosophy, but rather illustrative of a difficulty inherent within the project of establishing an existential approach to ethics. Sartre recognizes this failure, admitting that " $[\mathrm{w}] \mathrm{e}$ are never we except in the eyes of others [... the] effort to salvage human totality cannot occur without positing the existence of a third party, distinct in principle from humanity" ${ }^{12}$. And if the we-object is pure external construct, the we-subject is likewise, for Sartre, pure internal construct: "the experience of a we-subject is a pure psychological and subjective event in a singular consciousness" ${ }^{13}$. The problem for any existential ethics is, it would seem, none other than that of the ontological solitude of the existing subject. And as Sartre clearly points out, there appears to be no solution for establishing an ethical grounding for moral responsibility, or for the ethical requirement, without recourse to a third party, to some form of transcendence, be it through God, through the community, through discourse practices or the "logos of language" ${ }^{14}$ as Habermas suggests, or any other principle distinct from human existence itself. Kierkegaard/Climacus already formulated this difficulty in the Concluding Unscientific Postscript, noting that "ethically (ethisk) there is no direct relation between subject and subject" ${ }^{15}$. Yet the problem resides precisely here for the existential account, since if we appeal to something beyond the individual existing subject, then we can no longer, it would seem, take existence as our starting point. If indeed we are what we are, at least partially, because of an Other, we can no longer admit the radical subjectivity Sartre sought to establish, and the radical notion of responsibility that this entailed.

Of course, we may not wish to maintain Sartre's radicalized notion of subjectivity. Yet, this illustration is more generally indicative of a problem

${ }^{10}$ Rachel Bespaloff, "Lettres à Boris de Schlœzer (I),” ed. Olivier Salazar-Ferrer, Conférence, no. 16, 2003, p. 450 (our translation).

${ }^{11}$ Jean-Paul Sartre, L'être et le néant, Paris: Gallimard 1943 (1998), p. 271 (our translation).

12 Ibid., p. 463.

${ }^{13}$ Ibid., p. 466.

${ }^{14}$ Jürgen Habermas, Die Zukunft, p. 26.

15 SKS 7, 293 / CUP1, 321. 
with secular existential ethics as such. For an existential approach to ethics always presupposes some notion as to what an existing human being is as subject, and this ontological presupposition is not indifferent with regard to the origins of the moral requirement. If we do adopt a Sartrean-type approach, and assume that the coming into existence of the individual is contingent, arbitrary thrownness into the world, it makes sense to situate the origin of the moral requirement within the individual, as Sartre does: beginning with ourselves, we come to recognize other human beings. Within this context, it makes sense to speak of the primary moral requirement as ability to be ourselves, authorship of our lives, self-legislation. If the ethical requirement is immanent in this sense, however, it is difficult to see how we could ever come to a satisfactory account of our moral responsibility toward others, or of how others come to count for us. If, however, we wish to appeal to some third-party principle in order to explain the ethical requirement, then we are implicitly admitting a very non-Sartrean ontology: that the coming into existence of an individual depends upon some givenness, that our existence is not purely contingent, that it is rather dependent upon some external Other (be it society, parents, language, God...). And if our existence is given, the ethical requirement must to some extent be given as well, external or transcendent to us as individuals. Yet if that is the case, we can no longer maintain that the fundamental ethical requirement is the ability to be ourselves. In other words, any existential account of ethics leaves us with an alternative hinged upon our ontological view of human nature. Either we admit that human existence is contingent, arbitrary, in which case we can conceive of a free and autonomous self-construction on the part of the individual, but not of how our responsibility toward others could be established. Or we must assume that our existence is not entirely contingent, that life is in some way "given" or "granted" to us (whether in a theological or secular framework), in which case the notion of ethical demand and responsibility are also already outside of ourselves, and the fundamental ethical question cannot thereby be one of the ability to be oneself, of complete moral autonomy.

The flaw in Habermas's analysis of the problem of liberal eugenics is that it unwittingly subsumes this either/or. When appealing to Kierkegaard, Habermas evokes the fact that the ability of the individual to construct himself within the social sphere is only possible because each individual's existence is contingent and independent of any intentional project on the part of a third party. Third-party intervention on the biological constitution 
of a human being could render access to the ethical impossible, according to Habermas. In making this claim, Habermas is much closer to a Sartrean conception of the thrownness of individual existence than to a Kierkegaardian understanding of human nature, despite his citing of Kierkegaard. At the same time, Habermas seeks to maintain that the ethical requirement, or moral existence, comes from outside the individual, from his dependency upon social contexts and interactions. Though he admits to holding a much weaker position than that held by Kierkegaard or other religious thinkers, for whom the appeal to a transcendent power is necessary, he nevertheless sees the social structuring power of language as that through which a "'proper' ethical self-understanding" is "given" (gegeben) ${ }^{16}$. This power of language functions as a secularized version of the transcendent principle in the Habermasian context, since language is always outside of the individual, is not the property of any particular person, and is thereby that which is always already present, the context within which particular individuals define themselves within and against the structures of preexisting norms ${ }^{17}$. Habermas recognizes that this is a "deflationist" understanding of the absolute Other, ${ }^{18}$ but suggests that this "weak proceduralist reading of 'Otherness" preserves the criteria for absoluteness (Unbedingtheit) by transposing it to the sphere of the inter-subjective or the trans-subjective ${ }^{19}$.

While this solution does seem to resolve the dilemma inherent in existential accounts of ethics, Habermas's argument in Zukunft is unconvincing precisely because he is unable to demonstrate how the existential requirement of self-appropriation relates to the normative requirement of responsibility toward others. This is apparent in Zukunft, and illustrated by Habermas's quite ambiguous treatment of Kierkegaard in the text, making Kierkegaard into a privileged yet absent interlocutor, and inciting us to wonder whether Habermas is not artificially drawing Kierkegaard into dialogue. References to Kierkegaard can only be found in the introductory chapter of the work, while Kierkegaard is strangely absent in the following discussions about moral status and eugenics. And Habermas's appeal to Kierkegaard situates the latter within a post-metaphysical context where "philosophy no longer has the presumption of furnishing responses having a character of obligation to questions about modes of personal and

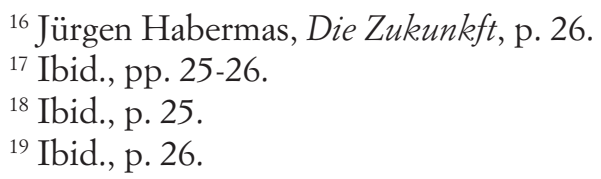


collective life" ${ }^{20}$. As Karin Christiansen has pointed out: "Because he does not succeed in explaining the relationship between the existential analysis and the mainly empirical, sociological and psychological observations he makes, [Habermas] renders himself vulnerable to critique from researchers within a number of different disciplines" ${ }^{21}$. On purely philosophical grounds, Habermas's argument is particularly weak insofar as it relies on an extremely fragile notion of what constitutes a human existence. As such, Habermas's understanding of human life renders the appeal to an existential ethics ineffectual, and suggests that at best Kierkegaard's existential ethics can offer us an understanding of what constitutes "a life which is not a failure" (eines nicht verfeblten Lebens) ${ }^{22}$.

II. A Confusion of the Categories: The ontological flaw in Habermas's account of buman nature and the appeal to an existential etbics

For Habermas, it is the individual's capacity to assume himself within a social context, against the varying forms of dependency that his biological structure and shared, collective existence force him to engage in, that shape the ethical as the very possibility for assumed life stances and responsibility. Selfhood is an act of rational self-appropriation, and ethics, or more precisely "the moral attitude," is thus seen by Habermas as "a constructive response to the different forms of dependency which stem from the fact that the organic apparatus is unachieved or incomplete, or that corporeal existence is in a state of sustained weakness" ${ }^{23}$. According to this account, our dependency upon others stems from the fact that we cannot exist outside of our relationships to others, through which, however, we must partly give ourselves up, and thus our moral state is one of perpetual vulnerability. Habermas thus construes the moral sphere as a palliative to that vulnerability, the only way in which we might regain the responsibility for our lives and the human dignity whereby we can be individuals. It is through moral community that we are able to set aside the weaknesses inherent in our nature, through the constitution of rules and norms which we set up mutually and reciprocally, and which must apply equally to all members of the community. According to Habermas, therefore:

\footnotetext{
${ }^{20}$ Ibid., p. 11.

${ }^{21}$ Karin Christiansen, “The silencing of Kierkegaard,” p. 154.

${ }^{22}$ Jürgen Habermas, Die Zukunft, p. 27.

${ }^{23}$ Ibid., pp. 62-63.
} 
Autonomy is [...] a precarious achievement of finite existences, which can only acquire something merely resembling "strengths" on the condition that they be well aware of their physical frailty and their social dependence. If this is the "grounds" of morals, its "limits" can also be explained therefrom. It is the universe of possible interpersonal relations and interactions which is, at once, demanding and capable of moral regulations. It is only in this network of relations of recognition, legitimately regulated, that men can develop and preservesimultaneously along with their physical integrity—a personal identity ${ }^{24}$.

The problem that the development of modern scientific techniques, and more specifically eugenics, poses for such an understanding of ethics and of personal identity, is according to Habermas inherently linked to the fact that such techniques and practices necessarily undermine the presupposition of equality upon which normative regulations can be constructed. For, as Habermas underscores, the ability to modify one's own biological constitution, and even more so that of other beings, depends on preferences and choices which irrevocably disrupt the fundamental understanding of all moral beings as free and equal individuals, leading to the "instrumentalization of [...] human life" ${ }^{25}$. More than simply a problem specific to certain individuals, Habermas asks whether "the technicization of human nature" will lead to a state where "we will no longer be able to understand ourselves as ethically free and morally equal beings orienting ourselves through norms and reasons," and as such, where our lives will be devoid of meaning and no longer worth living ${ }^{26}$.

We would argue that Habermas's understanding of the relationship between human nature as biological condition and moral nature as socially constructed is fundamentally confused. In attempting to explain both the grounds and limits of morality as stemming from the biological vulnerability of human beings as finite, dependent organic structures, Habermas is really making two very different claims about the nature of the moral requirement. On the one hand, he suggests that it is our biological frailty as finite beings incapable of existing without the aid of others that establishes the moral demand. This essentially comes down to the idea that moral responsibility is immanent within human nature itself, responsibility toward others is inherently nothing more than the condition for the subsistence of the individual and the species. On the other hand, Habermas portrays the

\footnotetext{
${ }^{24}$ Ibid., pp. 63-64.

${ }^{25}$ Ibid., p. 58.

${ }^{26}$ Ibid., p. 74.
} 
moral sphere as that through which the individual becomes more than just a member of the species, the context through which the biological being becomes a person, capable of autonomy and personal identity. According to this view, the moral requirement is no longer immanent within human nature, but rather transcendent or distinct from the existence of any determinate human being as such.

These two claims may not be incompatible. Yet, since Habermas does not articulate the means by which they may coexist, he fails to give a convincing account as to why the appeal to an existential ethics might be necessary with regard to the questions that the development of modern scientific practices, and more specifically eugenics, pose for understandings of human nature and ethics. Is moral requirement inherent in human nature itself, so that a modification of human nature might eliminate this requirement? Or is the moral requirement transcendent to human nature, and if this is the case, why should a modification of human nature have an impact on the ways in which individuals relate to themselves through the moral sphere? One of the problems in Habermas's argument is that he fails to distinguish between the notion of the human being, as a biological physical reality, and that of the self, in its subjective and psychological dimensions. Or, in other words, between the notion of human being as a static reality or fact, and the notion of self as a dynamic relationship.

This is where an appeal to Kierkegaard would have been extremely useful for Habermas; indeed, Kierkegaard clearly distinguishes between the notions of "self" (Selv) and "human being" (Menneske), writing that "a human being is still not a self" ${ }^{27}$. Being a self, for Kierkegaard, requires more than merely existing as a human being. Selfhood is defined by Kierkegaard essentially as relational: "The self is a relation that relates itself to itself or is the relation's relating itself to itself in the relation." ${ }^{28}$ Or, as Patrick Stokes notes in his recent book, The Naked Self, Kierkegaard locates selfhood "in a relational dynamic whereby a mass of psychological facts and dispositions relates to itself and its environment in an irreducibly first-personal way. It is in the specific way in which this psychology relates to itself that a human being comes to constitute a self" ${ }^{29}$. According to this perspective, the locus of selfhood can be seen as relating both inwardly and outwardly, both to one's

27 SKS 11, 129 / SUD, 13.

${ }^{28}$ Ibid.

${ }^{29}$ Patrick Stokes, The Naked Self: Kierkegaard and Personal Identity, Oxford: Oxford University Press 2015, p. 13. 
own organic and psychological nature and to the environment. In this sense, the double structure proposed by Habermas_-man as finite, vulnerable biological being, and man as immersed within an environment or context (the moral sphere) through which he becomes capable of freedom-makes sense. Human selfhood, according to a Kierkegaardian view, depends on the individual's ability to relate both to the facticity of his own being and to the external environment in which he evolves and interacts in a dynamic and first-personal mode. Yet Kierkegaard takes this analysis a step further, noting that there are two ways of understanding this relation: either it "must have established itself or have been established by another" ${ }^{30}$.

Here, we return to the abovementioned problem of the understanding of existence as either contingent or as given/granted. If we understand the self as capable of establishing itself by itself, then we have to admit that the self is undetermined by any transcendent principle. A fully autonomous self is only ontologically conceivable insofar as we understand its existence as depending upon no act through which some form of determination is given or granted. As soon, however, as we render the existence of the self dependent upon some form of givenness, this conception no longer makes sense. A self established by an Other cannot be seen as isolated existence, fully capable of autonomous self-determination, and as the origin of moral requirement. Kierkegaard's own response to this either/or is clear: the self is established by an Other, and can only be construed as full selfhood when seen as being before God. Whether we accept this position or not, however, Kierkegaard's notion of selfhood, and the dichotomy he confronts us with, clearly demonstrate that Habermas's double-positioning of the moral requirement is ontologically flawed. If we assume the self establishes itself, then we have to understand every individual being as a separate, isolated existence whose freedom to determine himself is absolute, yet in this case, we have no grounds for establishing moral requirement. If on the other hand we understand the self as established through an Other, we necessarily limit the individual's autonomy, but we gain the possibility of establishing moral requirement through the same givenness through which self is granted. Though Sartrean or Heideggerian models of existential ethics portray the individual self as self-granting and self-legislating, Kierkegaard notes that any understanding of the individual as isolated, separated being can only lead down to the impossibility of founding universal moral requirement, or anything resembling a moral goal or moral criteria: "If the individual is

\footnotetext{
${ }^{30}$ Ibid.
} 
isolated [Er Individet isoleret], then either he is absolutely the creator of his own fate, and then there is nothing tragic anymore, but only evil [...]; or the individuals are merely modifications of the eternal substance of life" ${ }^{31}$. And Kierkegaard understands the origin or moral requirement as something which cannot and "did not arise in any human being's heart" 32 , and thereby must be transcendent or given.

In claiming that the contingency upon which an individual's coming into the world is a necessary factor for that individual's being able to freely choose himself within the social sphere, Habermas makes an important category mistake. He assimilates the necessity, or facticity, of individual being (a human being) with the ethical possibility of becoming (a self), and thus ultimately holds an ontologically untenable position, which posits life (and moral requirement) as simultaneously given and contingent. This confusion further incites Habermas to confuse what are really two distinct types of metaethical questions present in Kierkegaard's writings: those pertaining to the objective groundings of moral principles, and those pertaining to subjective appropriation of those principles as engagement and responsibility.

Indeed, in his treatment of Kierkegaard, Habermas focuses uniquely on the existential question of the individual's ability to be himself, which is really a question of subjective appropriation, and not one of the groundings of moral requirement. According to Habermas, as far as the grounds for universal normative ethics are concerned, Kierkegaard has little to say. To the contrary: "All of his attention is in fact pointed to the structure of the 'ability-to-be-oneself', that is, to the form of an ethical auto-reflection and the choice for oneself, which is determined by an infinite interest in the success of [the individual's] life project" ${ }_{33}$. Habermas suggests that for Kierkegaard, all that matters is the individual's ability to appropriate his own life-biography for himself, to become the author of his own life history. It is only insofar as the individual is free to completely assume all of his present, past and future positions and choices, all of his actions, that a person can be considered to be free and, as such, a truly noninterchangeable singular subject. Of course, Habermas recognizes that within Kierkegaard's theological perspective, such authorship of oneself only takes on meaning in relationship to God, and that the objectivity of any ethical stance depends on a higher power, the only means by which

\footnotetext{
${ }^{31}$ SKS 2, 158-159 / EO1, 160.

32 SKS 9, 32 / WL, 25.

33 Jürgen Habermas, Die Zukunft, p. 19.
} 
the demands of ethics can be reconciled with what Habermas portrays to be an infinite self-interest. Nevertheless, Habermas portrays Kierkegaard's ethics as one which associates autonomy with authorship, and suggests that from a Kierkegaardian perspective, a life deprived of such possibilities of authorship—which may result from human intervention on the biological constitution of other humans-would be a life without meaning.

It is however important to note that the notion of freedom that Kierkegaard develops with regard to the ethical stage (in Either/Or ${ }^{34}$ ) is quite different from the position Habermas seeks to ascribe to him, suggesting that the ability-to-be-oneself entails complete control over one's actions and decisions. For Kierkegaard, to the contrary, absolute freedom does not, of course, mean absolute liberty of action, or the idea that we can always choose otherwise. It may not even mean that we can choose any of our acts at all. What it is that our freedom enables us to choose is not our acts, but our selves; or, as Kierkegaard affirms, "greatness is not to be this or that but to be oneself, and every human being can be this if he so wills it" 35 .

None of our past choices, none of our present circumstances or social roles, no institution or higher being can ever replace the absolutely individuating and radically isolating act whereby we must take full responsibility for our own freedom. But this "radical subjectivity" ${ }_{6}$, as Kelly Oliver terms it, is in no way a form of subjectivism in Kierkegaard's thought. For Kierkegaard, the responsibility for our freedom does not entail that the ethical requirement is the individual's own construction. As Kelly Oliver has pointed out, the main problem with arguments on liberal eugenics is that they all "begin with some version of a liberal sovereign individual who has freedom of choice that must be protected." ${ }_{37}$ Yet as she notes, this is clearly not Kierkegaard's view. ${ }^{38}$ While she does not develop the question with regard to Kierkegaard, we would add that the problem in Habermas's reading is precisely that it fails to distinguish between the ontological question of human being and the ethical question of moral requirement. For Habermas, understanding the individual human being as undetermined, a

${ }^{34}$ Habermas refers mainly to the conception of the ethical developed in this text, and generally neglects the other dimensions of Kierkegaard's ethics.

35 SKS 3, 173 / EO2, 177.

36 Kelly Oliver, "Genetic Engineering: Deconstructing Grown versus Made", in Technologies of Life and Death: From Cloning to Capital Punishment, New York: Fordham University Press 2013, p. 37.

${ }^{37}$ Ibid., p. 26.

${ }^{38}$ Ibid., p. 37. 
product of mere contingency, is the only way in which to conceive of human responsibility.

\section{Kierkegaardian Existential Ethics and Liberal Eugenics}

Seen in this light, however, it is unclear why Habermas insists on the fact that the intervention of others' choices, their actions which effect our biological constitution, should have any impact at all on the freedom to choose our selves. Certainly, such actions may affect the biological conditions upon which we come into the world-our genetic makeup, the facticity which regulates certain historico-social facts of our determination. But if the choice of our selves is indeed absolute, there is no reason a priori why such decisions should have any more impact than, say, the natural processes of selection inherent in procreation or the basic biological determinism inherent in every human being's existence. In light of these reflections, it appears clear that Habermas's dialogue with Kierkegaard remains artificial because, in his desire to secularize the moral problems which eugenics poses for us, he nevertheless unavowedly retains an inherently religious view of human nature as sacred, while simultaneously attempting to argue that the reasons why eugenics should be regarded with caution are of a moral and legal nature. Yet these arguments are incompatible. Either we must assume, as Kierkegaard does, that human nature is itself the foundation upon which each individual becomes what he becomes, independent of external social factors and circumstances in which he later learns to navigate, in which case there is no reason a priori that the modification of man's biological constitution should influence possibilities of self-appropriation unless such modifications make human beings into something other than human beings (the creation of a new species). Or we can assume that the entire foundation of human selfhood is based on social, legal, linguistic, and political contexts in which the individual is inherently inscribed and against which he identifies himself, as Habermas does, in which case the generalization of eugenics and the modification of human biological constitution should not greatly modify the relations of recognition which presently exist in our rather unegalitarian societies.

It should be noted, however, that in the latter analysis, the emphasis should be placed on the notion of generalization. For the real philosophical problem inherent in the question is one that Habermas evokes but fails to develop in Zukunft: that of the liberalization of eugenic practices within a capitalized economy. Only one brief mention of this problem can be found 
in the text: "In liberal societies, it's the market, determined by the search for profit and the preferences linked to demand that will leave decisions [...] up to the individual choices of parents, and in general, to the anarchic desires of its users and clients" ${ }^{39}$. We would argue that this is the real issue for concern, which Habermas unfortunately fails to develop in Zukunft. For there is no strong argument enabling us to affirm that the choice of parents to have recourse to eugenics will strongly alter the existing political and social contexts through which our identities are constructed. Habermas insists on the idea that such practices might implement a fundamental inequality, since the programmed child will not be able to switch places with his programmer, not be able to re-appropriate himself and set himself upon equal footing. Yet this argument fails to recognize that in natural social conditions, this is already the case ${ }^{40}$.

The natural son cannot change places with his father any more than a biologically altered son could. This is precisely the argument that Peter Sloterdijk presents in Regeln für den Menschenpark, where he suggests that the contemporary questions posed by bioengineering and prenatal selection as technical possibilities are really no more than an extension of the processes of selection, breeding and determination inherent within civilization itself ${ }^{41}$. With regard to Habermas's arguments, then, the problem of eugenics is not one of choice, but rather of the absence of choice. Eugenics poses a problem precisely because it is not preference which determines the individual, but rather the system which determines preferences, price and offer ultimately leading to a predetermined selection of traits and characteristics which will determine not only individual genetic makeup, but also social classes and structures.

With regard to this debate, would a Kierkegaardian approach to existential ethics have anything to say? Habermas is quick to dismiss Kierkegaard, suggesting that an existential ethics can provide no grounding for the constitution of normative moral requirements or principles. Yet it is not clear that this is indeed the case. Where modern (twentieth-century)

${ }^{39}$ Jürgen Habermas, Die Zukunft, p. 86.

${ }^{40}$ Kelly Oliver insists on the importance of political and social preferences, which are generally overlooked in speculative debates on the topic, noting that while of course there is no way of saying that it is morally preferable for an individual to have, say, a certain color of hair or skin, these traits may represent a distinct advantage or disadvantage within socio-political contexts, and thus can have a major impact on the individual's ability to exist within society (Kelly, Oliver, "Genetic Engineering," pp. 28-29).

${ }^{41}$ Peter Sloterdijk, Regeln für den Menschenpark. Ein Antwortschreiben zu Heideggers Brief über den Humanismus, Frankfurt: Suhrkamp 1999. 
accounts of existential ethics fail to demonstrate how an understanding of moral requirement could be anything other than subjective, since they are founded on the presupposition of the ontological solitude of the human being as isolated subjectivity and derive therefrom a conception of moral solitude, this second movement is not necessary. It is true that, in many respects, Kierkegaard does seem to defend the position that ethical existence is always that of a subject incapable of relating directly to another subject. In the Postscript, Kierkegaard/Climacus remarks that: "existing ethically (ethisk) [...] the individual human being stands alone" ${ }^{2}$. Separation does seem to be an existential condition, in Kierkegaard's view: not only is the subject separated from other subjects, but also from the different dimensions of himself. However, "standing alone" does not imply, for Kierkegaard, that man is self-legislating, the author of his own fate, and the creator of moral norms, principles, or requirement. Rather, if in ethical existence, the individual human being stands alone, this only refers to the fact that each individual is himself responsible for bimself, that no one can be judged in his stead. He is responsible for what he is, even when he cannot choose; as such, Kierkegaard/Judge Wilhelm writes that "even the lowliest of individuals has a double existence. He, too, has a history, and this is not simply a product of his own free acts. The interior deed, on the other hand, belongs to him and will belong to him forever; history or world history cannot take it from him" ${ }^{43}$. Standing alone, or ontological solitude as we have termed it, simply refers to the individual "interior deed," and not to the origins of moral requirement. In other words, the individual stands alone insofar as it is his task, and his alone, to subjectively appropriate for himself his own freedom and assume the responsibility that this entails.

However, if the ethical can been understood as an individual task, it is precisely because the ethical is not for Kierkegaard something posited within the individual - to the contrary, the ethical is the domain of the universal, and only as such can the moral requirement be anything other than arbitrary construct. As such, ethics can only be understood as a science based on universal postulates, the first of which is that: "Ethics (Ethiken) focuses upon the individual, and ethically understood it is every individual's task to become a whole human being, just as it is the presupposition of ethics that everyone is born in the state of being able to become that" ${ }^{4}$.

\footnotetext{
${ }^{42}$ SKS 7, 295 / CUP1, 323.

${ }^{43}$ SKS 3, 171 / EO2, 175.

${ }^{44}$ SKS 7, 316-17 / CUP1, 346.
} 
The moral requirement thus stems, for Kierkegaard, not from existence or human nature itself, but from our ability to understand our existence from a universal point of view. Thus, the ethical choice is not one of relative norms or values, "this or that," but rather the choice of "the absolute" and of "eternal validity" 45 . For every individual, this is a task which he must accomplish alone, but which is only possible because he is precisely not alone in the world.

Does this entail that an existential ethics supposes that there are no universal norms to which we can appeal, as Habermas suggests? While Kierkegaard is highly critical of the variability of socially constructed moral norms, which are obviously contingent and relative from one society to the next, his works do point to some universal principles, and insist on the fact that existential choice "is not lawless; neither does it itself establish the law" 46. Rather, there are some universal principles that Kierkegaard articulates in his works, the two most fundamental being (1) the duty to love one's neighbor as oneself, which is "essentially to will to exist equally for unconditionally every human being" rejecting all consideration of contingent, socially or physically rooted disparities between individuals ${ }^{47}$, and (2) the duty to judge oneself more severely than one judges others, or perhaps more radically the obligation to make "everyone judge only himself" 48 .

Are these principles sufficient to respond to the complex questions that modern technologies raise about the future of human nature and morality? Habermas is perhaps right to suggest that in the face of these developments, only a return to an existential ethics can offer a solution. However, in his appeals to Kierkegaard, Habermas places the criterion of living a meaningful life on the wrong side of the debate. A Kierkegaardian existential ethics, which insists on our duties to ourselves and others, our judgments of ourselves, would ask the question in a very different manner: what does it say about me, that I believe that I could only love my child if he had a particular hair or skin color, particular intellectual or physical capacities? What does it say about me, that I grant more importance to the accidental attributes of my future child than to the "eternal validity" of his self? What does it say about my own life, that I think that it would be more meaningful if future generations had certain capacities, traits, and dispositions?

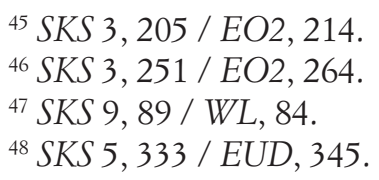


In Works of Love, Kierkegaard suggests that the only way in which a person's ability to love is fully made manifest is through his relations to those who are not living: "if you want to ascertain what love there is in you or in another person, then pay attention to how he relates to the dead" ${ }^{49}$. It is only through the relationship to the dead that the living are "disclosed" 50 in all their fullness, only in relationship to the absent that they may become fully present. In all worldly interactions, we see ourselves and others through our relationships to others, we understand ourselves subjectively by objectifying others. Yet "[o]ne who is dead is no actual object; he is only the occasion that continually discloses what resides in the one living who relates himself to him or that helps to make manifest the nature of the one living who does not relate himself to him" ${ }_{51}$. This argument could also be made for the notyet living, the yet-unborn children of future generations. Their absence is an appeal to our own self-examination, to our judgment of ourselves and the principles upon which we ourselves act and deploy our freedom.

Kierkegaard certainly never envisaged the possibilities that modern science, genetic engineering, cloning and other technological developments have opened up for humanity. Yet his works do offer a path for thinking through these questions. As such, Habermas is right to suggest that a return to existential ethics may be the only solution faced with a situation in which no norms or precedents can determine what is right or good. However, he is mistaken in situating the existential question within the possibilities of future generations. There is no strong argument to say that genetically modified individuals would be less able to "be themselves" simply because of genetic alteration. The real questions that we ought to ask-from the perspective of an existential ethics-are not about others, but rather about ourselves. How can we be sure that the choices we are making are really our own, and not dictated by the social and political contexts in which we find ourselves? How can we be sure that we are choosing absolutely, in a world where "we are everywhere lavishly regaled with pragmatic rules, a calculus of considerations" that point us in the direction of "habitual and excessive relativity"? ${ }^{52}$. How can we understand our own lives as meaningful, if we place the value of the life of another in non-essential attributes such as physical characteristics or capacities?

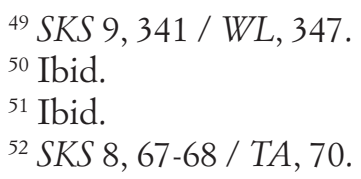


Kierkegaard's existential ethics invites us to understand that every individual, as a self, has infinite eternal value, and that ethics is precisely the recognition of this infinite eternal value. While Kierkegaard certainly understands this from a religious perspective, there is no need to appeal to a form of divine transcendence or creation to maintain this presupposition. From a secular perspective, we can just as well understand ourselves as selves as beings of infinite eternal value-indeed, this may well be the criterion upon which we can understand ourselves as selves at all. This is not an appeal to an ideal of the individual as sovereign and self-legislating, but merely a fact of human experience: if our lives have meaning for us at all, it is because we are passionately engaged in them. We cannot understand ourselves as beings of only finite value without falling into despair. Whether this corresponds to any actual fact about reality is not the question-it is what we are as selves, and not as mere biological beings, that opens up the dimensions of the ethical.

To the question of liberal eugenics, Kierkegaard could thus offer the following (secular) response: in choosing to engage in such practices, what is at stake is not the freedom of future human beings, but rather our own freedom. Our ability to understand ourselves as selves requires that we attribute some absolute, eternal (yet non-substantial) value to the notion of selfhood. Yet this is only possible if we understand our lives as more than mere finite existences-be they biological or social. And it requires an appeal to the universal dimensions of the ethical, to the infinite relationships in which we engage in with others. Yet as Kierkegaard/a "pastor from Jylland" remarks, the only way by which we can engage with others infinitely is by first understanding that with regard to others, "we are always in the wrong" ${ }^{3}$ : "Therefore, wishing to be in the wrong is an expression of an infinite relationship, and wanting to be in the right, or finding it painful to be in the wrong, is an expression of a finite relationship" ${ }^{54}$. Making irreversible choices for other individuals will not in itself deprive them of the possibility to be themselves and to lead a meaningful life-although this certainly might have an impact on the social and political existence of these individuals. But it would deprive us, those who choose, of our own freedom and meaningfulness: it would condemn us to engaging with others only through finite relationships, and to seeing our own lives as mere finite, meaningless existences.

53 SKS 3, 326 / EO2, 346.
54 SKS 3, 327 / EO2, 348.

Estudios Kierkegaardianos. Revista de filosofía 2 (2016) 


\section{Concluding Remarks}

As progress in biotechnologies continues to shape and reshape our view of nature, the focus of many debates has surreptitiously shifted. When Dolly was cloned in 1996, the major debate was whether cloning (and especially human cloning) was an acceptable practice at all; twenty years later, the major question is now whether to limit cloning to purely therapeutic practices, or extend it to reproductive cloning. Decried after the World War II, eugenics is now once again on the verge of becoming a socially accepted practice, at least as far as the early detection and prevention of serious and potentially handicapping illnesses is concerned, and many are the proponents of "designer babies." Almost without our being aware of the shift, the question has become one of the limits we impose upon our technological prowess, and no longer one of whether these technologies should be used at all. In light of these debates, normative ethics indeed has little to offer, as Habermas points out, aside from the Precautionary Principle. Yet however necessary this principle may be, it is clear that it can hold off neither the development of new biotechnologies, nor the evolution in mentalities and social norms that these entail. However careful we may be in attempting to foresee the potential social, political, and biological effects of new technologies, we simply have no scientific grounding upon which to draw our conclusions-and we will have no such grounding until these effects have already become the norm.

Despite the inconsistencies inherent in Habermas's Die Zukunkft der menschlichen Natur, this text has one great merit: Habermas recognizes here that a strictly normative approach to ethics cannot offer a response to many of the questions that scientific developments are bringing up with regard to the future of human nature, and argues for a revival of existential ethics. Contrary to Habermas's argument, however, existential ethics is not a "postmetaphysical” approach to the Good, but rather an inherently metaphysical questioning of existence. What is human reality? What is the individual human being, what is the nature of individual experience? What value and meaning does existence have? These are questions to which we cannot offer a normative, societal response.

While existential ethics and normative principles are not necessarily mutually exclusive, existential ethics places the emphasis on the criteria for meaningful selfhood, rather than on the principles that guide our actions. In order to make choices, to act in ways which can be construed as meaningful, 
we first have to understand ourselves as beings whose lives have meaning for us. While Sartre and Heidegger's radicalized understanding of human subjectivity seems to leave no room for ethical concern for others, existential ethics does not necessarily have to lead down to solipsism. Kierkegaard's notion of the self as relating to itself through another offers a path to understanding that the meaningfulness of our existence is dependent upon the ways in which we engage with others. With regard to contemporary debates, this approach is all the more necessary, since it invites us to see the future human beings these decisions will impact not as mere objects of theoretical reasoning, but as real, individual human beings whose selfhood is at stake.

Existential ethics cannot, and ought not, replace normative debates about the role and effects of biotechnologies in our societies. However, it invites us to return to the fundamental questions that these debates often occult, and to examine the beliefs and suppositions that underlie many of our positions. For example, many proponents of the application of eugenic practices for therapeutic purposes claim that these practices will enable us to eliminate illnesses leading to severe handicaps. We often forget, however, that this desire for progress already contains a normative value judgment: that the life of a handicapped person is somehow less good, less worth living, than the life of a non-handicapped person, and that the handicapped person would have led a "better" life had he not suffered from this handicap. Are we justified in making such claims? Do we indeed have the authority to decide what constitutes for another a "good" or "better" life? Existential ethics encourages us to rethink our positions and normative values, and to understand that such normative judgments are not legitimate considerations. Habermas is certainly right to suggest that what is important in existential ethics is the possibility of constructing oneself as self, however, he fails to see that the problem inherent in normative debates is not one about the possibilities of future individuals, but rather one of the ways in which norms are already constructed in our present societies. And though existential ethics may not be able to respond to all questions, it nevertheless leads to the construction of some normative principles. Most importantly, it suggests that since no individual has the experience of another's life, no one has the right to decide for another whether his life is meaningful, whether his life is worth living. And therefore, it is never legitimate to act in such a way that we surreptitiously make that decision in his stead. 


\section{Bibliography}

Bespaloff, Rachel, "Lettres à Boris de Schlœzer (I)," ed. Olivier Salazar-Ferrer, Conférence, no. 16, 2003, pp. 407-59.

Christiansen, Karen, "The Silencing of Kierkegaard in Habermas' Critique of Genetic Enhancement," Medicine, Health Care and Philosophy, no. 12.2, 2009, pp. 147-56.

Habermas, Jürgen, Die Zukunft der menschlichen Natur: Auf dem Weg zu einer liberalen Eugenik?, Frankfurt am Main: Suhrkamp 2002 (2005).

Kierkegaard, Søren, Concluding Unscientific Postscript to Philosophical Fragments, trans. Howard V. Hong and Edna H. Hong, Princeton: Princeton University Press 1992.

_Eighteen Upbuilding Discourses, trans. Howard V. Hong and Edna H. Hong, Princeton: Princeton University Press 1990.

_ Either/Or, Part I, trans. Howard V. Hong and Edna H. Hong, Princeton: Princeton University Press 1987.

— Either/Or, Part II, trans. Howard V. Hong and Edna H. Hong, Princeton: Princeton University Press 1987.

- The Sickness Unto Death, trans. Howard V. Hong and Edna H. Hong, Princeton: Princeton University Press 1980.

— Two Ages, trans. Howard V. Hong and Edna H. Hong, Princeton: Princeton University Press 1978.

Works of Love, trans. Howard V. Hong and Edna H. Hong, Princeton: Princeton University Press 1995.

Oliver, Kelly, "Genetic Engineering: Deconstructing Grown versus Made", in Technologies of Life and Death: From Cloning to Capital Punishment, New York: Fordham University Press 2013, pp. 21-50.

Sartre, Jean-Paul, L'être et le néant, Paris: Gallimard 1943 (1998).

Sartre, Jean-Paul, L'existentialisme est un bumanisme, Paris: Gallimard 1946 (1996).

Sloterdijk, Peter, Regeln für den Menschenpark. Ein Antwortschreiben zu Heideggers Brief über den Humanismus, Frankfurt: Suhrkamp 1999.

Stokes, Patrick, The Naked Self: Kierkegaard and Personal Identity, Oxford: Oxford University Press 2015. 